\title{
THE MANAGEMENT DEVELOPMENT OF PEDAGOGICAL SKILLS OF TEACHERS-CLINICISTS OF THE HIGHER MEDICAL EDUCATION INSTITUTION
}

\section{УПРАВЛІННЯ РОЗВИТКОМ ПЕДАГОГІЧНОЇ МАЙСТЕРНОСТІ ВИКЛАДАЧІВ-КЛІНІЦИСТІВ ЗАКЛАДУ ВИЩОЇ МЕДИЧНОЇ ОСВІТИ}

\section{Tatjana Zakusilova ${ }^{1}$}

DOI: https://doi.org/10.30525/978-9934-588-15-0-9

Abstract. The subject of the research is: educational management in medical universities, modernization of the educational environment at the medical university as the main pedagogical condition for professional training of future medical professionals, pedagogical skill of teachers-clinicians. The purpose of the study is to determine the mechanisms of managerial influence on the process of development of pedagogical skills of teachers-clinicians of institutions of higher medical education. The scientific discussion of the problem raised is covered. It has been found that due to the increasing urgency of the problem of protection and promotion of human health, new requirements for the content and quality of training of future doctors are emerging. The factors contributing to the creation of professionally oriented educational environment adapted to the needs of future professional activity are considered: 1) establishment of humanistic interpersonal relations of future medical professionals; the use of individual, collective educational and practical tasks that stimulate the development of the ability to work in a team; 3) combination of individual and collective forms of educational activity of medical students; 4) designing occupational health situations that stimulate the development of professional awareness and culture of communication between students as health professionals; 5) development of future health workers' independence; 6) involvement of future medical professionals in project activities aimed at mastering program material and

${ }^{1}$ Candidate of Pedagogical Sciences, Lecturer of Department of the Health Care, Social Medicine and Medical Expertise, Zaporozhye State Medical University, Ukraine 
practical skills; 7) strengthening the professional orientation of training; 8) search of new technologies of realization of cooperation of the teacher with students in the educational process for joint solving of professional problems; 9) the development of methodological bases for the role behavior of future medical professionals; 10) increase of competitiveness and mobility of graduates of higher medical institutions. It is emphasized that pedagogical skills of clinical teachers should be constantly displayed: during training sessions (both lectures and practicals, seminars, laboratories) and in the course of extra-curricular work. It is noted that the renewal of the system of scientific and methodological work is inextricably linked with the development of new pedagogical thinking, the study of innovative teaching technologies based on computer support of educational activity and intensification of the educational process; increases the efficiency of the educational process and the professional level of teachers. Emphasis is placed on the need to create methodological support for the exchange of advanced pedagogical experience of teachers of medical colleges. Emphasis is placed on the introduction of innovative technologies to improve the pedagogical skills of clinical teachers. It is stated that it is necessary to create interactive networks, to provide academic mobility of students and teachers and, of course, medical practitioners. Thus, the article indicates that the following forms of work on improving the pedagogical skills of teachers-clinicians of the medical university were found to be effective and efficient: scientific-methodical seminar «Pedagogical technologies of forming the bases of future doctors' professionalism»; monthly workshops, methodological meetings; open lectures, seminars and practical classes; author's methodological recommendations and developments concerning the introduction into the medical college of the interactive forms and means of formation in future doctors of clinical thinking and culture of professional communication, which significantly influenced the improvement of the effectiveness of their professional training.

\section{1. Ветуп}

У сучасних умовах ринкової економіки, з урахуванням впливу екологічних чинників та негативних наслідків окремих галузей промислового виробництва на здоров'я людини, зростають вимоги до якості підготовки майбутніх медичних працівників, від професіоналізму 
яких безпосередньо залежить майбутнє здорової нації, що є запорукою міцного суспільства й успішного розвитку держави.

Викладач медичного ЗВО є менеджером освітнього процесу на своєму управлінському рівні. Управлінські функції завжди присутні в діяльності педагога, тому що в цьому й полягає сутність педагогічного процесу, який здійснюється на основі особистісно-орієнтованої парадигми в освіті. Навчальний процес, як правило, не тільки є детально продуманим, але й керованим.

\section{2. Освітній менеджмент в медичних 3 ВО}

Менеджмент (англ. management - управління, система управління) в освіті - сукупність стратегії, філософії, тренінгів, методів, засобів і форм управління освітнім процесом. 3 одного боку, менеджмент можна розглядати як науку, що робить вагомий внесок у розвиток суспільних відносин та сприяє реалізації суспільних потреб, а з іншого - як процес, що здійснюється апаратом управління чи категорією людей засобами реалізації визначеної системи функцій. У свою чергу, цей процес $є$ об'єктом дослідження науки менеджменту з метою його вдосконалення та адаптації до суспільних потреб.

На сучасному етапі розвитку суспільного життя однією з провідних галузей менеджменту стає освітній, який має свою специфіку та притаманні тільки йому закономірності. Така специфіка зумовлена особливостями предмету, продукту, знарядь та результатів праці менеджера освіти.

Менеджмент в освіті - це комплекс принципів, методів, організаційних форм та технологічних прийомів управління освітнім процесом, спрямований на підвищення його ефективності.

Фахівці з проблем освітнього менеджменту виділяють такі його функції: 1) прийняття розумного рішення; 2) організація виконання прийнятих рішень, створення належних умов для ефективної роботи освітнього закладу, кожного учасника освітнього процесу, забезпечення мотивів та стимулів їх діяльності; 3) контроль виконання рішень. Розвиток теорії управління освітою викликав безліч трактувань цього явища, внаслідок чого й у практичній діяльності керування освітнім процесом виникли такі поняття, як педагогічний менеджмент, дидактичний менеджмент, менеджери освіти, навчально-пізнавального, навчально-виховного процесів. 
Основними функціями менеджменту в освіті визначають: прийняття розумного рішення; організація виконання прийнятих рішень, створення належних умов для ефективного освітнього процесу, кожного його учасника; забезпечення мотивів та стимулів їхньої діяльності; контроль виконання завдань тощо [1, с. 68].

Педагогічний менеджмент - це комплекс принципів, методів, організаційних форм і технологічних прийомів управління освітнім процесом, спрямований на підвищення його ефективності [32, с. 37]. Призначення менеджменту, власне, в освіті-створити освітнє середовище, що ефективно працює та відповідає сучасним вимогам, $є$ привабливим для реального та потенційного споживача. Педагогічний менеджмент розвивається в межах освітнього менеджменту, має свою специфіку у зв'язку з виконанням особливої функції - створення систем управління педагогічними процесами.

За визначенням В. Симонова [24, с. 29], педагогічний менеджмент це комплекс принципів, методів, організаційних форм і технологічних прийомів управління освітнім процесом, спрямований на підвищення його ефективності. На думку автора, освітній процес - це сукупність таких складових: навчально-пізнавального, навчально-виховного та самоосвітнього процесу.

На нашу думку, найбільш вдале визначення поняття «педагогічний менеджмент» пропонує В. Симонов, визначаючи його як комплекс принципів, методів, організаційних форм та технологічних прийомів управління освітнім процесом, який направлений на підвищення його ефективності та якості [там само].

Практична діяльність викладача як управлінця свого рівня добре простежується в навчально-виховному процесі вищого навчального закладу, що працює в інноваційному режимі. Йдеться про функції педагогічного менеджменту в діяльності викладача в умовах його роботи зі студентами, коли викладач постійно використовує нові підходи в організації навчального процесу, нові технології та засоби реалізації особистісно-орієнтованої системи освіти, що забезпечує результативність його роботи.

Відомо, що активні методи навчання (проблемні, евристичні) потребують набагато більше витрати часу, ніж традиційні (словесно-репродуктивні), тому що це не просто методи навчання, а методи організації навчальної діяльності на занятті. 
Менеджмент - це педагогічна діяльність сьогодення. Гарним викладачем вважають того, хто точно знає, чого він хоче домогтися в результаті навчання студентів за своїм предметом, розділом чи темою; того, хто вміє ставити чіткі цілі на конкретне заняття перед собою та студентами; того, хто вміє побудувати раціональну програму досягнення цих цілей, тобто грамотно спланувати свою діяльність та діяльність тих, кого навчають; того, хто спроможний ефективно проконтролювати хід та засвоєння студентами відповідних елементів навчальної інформації, проаналізувати результативність діяльності та зробити необхідні корективи.

За своєю структурою якісна педагогічна діяльність вже давно не відрізняється від управлінської, яка включає в себе: цілепокладання (також включає передбачення результатів); планування; створення умов; конструювання структури групи; стимулювання координацію; контроль.

Робота на етапі менеджменту дозволяє педагогу принципово підвищити свою компетенцію. Його мислення вже не є споживчим, виконавчим, обмеженим. 3'являються нові можливості для виявлення й подолання стереотипів. Головне - змінити стиль мислення. Викладач повинен навчитися управляти ймовірними процесами, впливаючи на результат опосередковано.

Кінцевим продуктом функціонування освітньої організації, як зазначає Л. Карамушка, є «живий» об'єкт, особистість - соціальна особа, залучена до суспільних стосунків, діяч (суб'єктів) цих стосунків» [9, с. 120].

Підвищення ефективності навчально-виховного процесу сьогодення визначається формуванням сучасних управлінських відносин, зростання керованості цього процесу.

На думку більшості дослідників з означеної проблеми, зокрема Т. Шамової, П. Третьякова, Н. Капустіна [33], процес керівництва складними імовірнісними системами (навчальна група, навчальне середовище, навчальний процес) за допомогою простих методів (випливає з кібернетичного закону розмаїтості, відкритого У. Ембі) не буде ефективним. Пізнання законів взаємодії елементів цих систем має своєю кінцевою метою використання їх на практиці на будь-якому рівні освітньої системи, в тому числі й на рівні навчальної групи. 
Управління процесом розвитку педагогічної майстерності викладачів-клініцистів закладу вищої медичної освіти - це послідовна, покрокова реалізація процедур навчально-пізнавальної діяльності, об'єктивна необхідність якої визначається новими підходами в організації освітнього процесу, що будується на особистісно орієнтованій основі в процесі навчання, на зміні самої позиції педагога як менеджера навчальної інформації студентів. Свою педагогічну діяльність у нових умовах педагог-викладач повинен будувати з опорою на науково обгрунтовані процеси управління.

Основними функціями менеджменту в освіті визначають: прийняття розумного рішення; організація виконання прийнятих рішень, створення належних умов для ефективного освітнього процесу, кожного його учасника; забезпечення мотивів та стимулів їхньої діяльності; контроль виконання завдань тощо.

Отже, менеджмент - це педагогічна діяльність сьогодення. Гарним викладачем вважають того, хто точно знає, чого він хоче домогтися в результаті навчання студентів за своїм предметом, розділом чи темою; того, хто вміє ставити чіткі цілі на конкретне заняття перед собою та студентами; того, хто вміє побудувати раціональну програму досягнення цих цілей, тобто грамотно спланувати свою діяльність та діяльність тих, кого навчають; того, хто спроможний ефективно проконтролювати хід та засвоєння студентами відповідних елементів навчальної інформації, проаналізувати результативність діяльності та внести необхідні корективи.

За своєю структурою якісна педагогічна діяльність не відрізняється від управлінської. Викладач медичного ЗВО є менеджером освітнього процесу на своєму управлінському рівні. Практична діяльність викладача як управлінця свого рівня добре простежується в освітньому процесі вищого навчального закладу, що працює в інноваційному режимі.

\section{3. Модернізація освітнього середовища в медичному $3 В О$}

Головною метою освіти України визнано створення умов для особистісного розвитку молодого покоління, здатного навчатися впродовж життя, створювати і розвивати цінності громадянського суспільства: сприяти консолідації української нації, інтеграції України в європейський та світовий простір як конкурентоспроможної та процвітаючої держави [15]. 
Науково-методичне забезпечення освітнього процесу в медичних ЗВО передбачає створення спеціальних організаційно-педагогічних умов, зокрема - модернізація освітнього середовища.

Термін «умова» трактується як:

- єдність об'єктивного та суб'єктивного, внутрішнього й зовнішнього, сутності та явища (Н. Яковлєва [34]);

- вираження відношення предмета до явищ, що його оточують і без яких неможливе його існування (Ю. Фролов [30]);

- сукупність об'єктів (речей, процесів, відносин), необхідних для виникнення, існування або зміни заданого об'єкта (В. Андрущенко $[29$, c. 234]);

- сукупність зовнішніх та внутрішніх обставин (об'єктивних заходів) освітнього процесу, від реалізації яких залежить досягнення поставлених дидактичних цілей (А. Нісімчук [16]);

- обставини, від яких залежить наявність чи зміна чого-небудь, зумовленого ними (І. Харламов [31]);

- обставини, що сприяють розвитку людини, формуванню іiї особистості та забезпечують ефективне й цілісне здійснення освітнього процесу [20];

- фактор (латинське factor - чинник), тобто рушій, причину будьякого процесу [26];

- необхідна обставина, яка вможливлює здійснення, створення, утворення чого-небудь або сприяє чомусь, що стає причиною-явищем, що породжує інше явище та прогнозує його специфіку, слугує підставою для дій, спонукою, мотивом, що зумовлює певні вчинки [4].

У психології дефініція поняття «умова» подається як сукупність явищ зовнішнього та внутрішнього середовища, що ймовірно впливають на розвиток конкретного психічного явища; до того ж це явище опосередковується активністю особистості, групою людей [27].

У педагогіці умова трактується як сукупність перемінних природних, соціальних, зовнішніх та внутрішніх чинників, що впливають на фізичний, психічний та моральний розвиток людини, його поведінку, виховання й навчання, формування особистості [25, с. 36].

У словнику професійної освіти дефініцію умови подано як сукупність динамічних природних, соціальних, зовнішніх та внутрішніх чинників, що впливають на фізичний, психічний, моральний розви- 
ток людини, його поведінку; виховання і навчання, формування особистості [22 с. 36].

На думку А. Семенової, педагогічні умови - це обставини, за яких відбувається цілісний продуктивний педагогічний процес професійної підготовки фахівців, опосередкований активністю особистості, групою людей [25].

Педагогічними умовами називають зовнішні обставини, які суттєво впливають на перебіг педагогічного процесу, що передбачає досягнення успішного результату процесу навчання, та спрямовані на підвищення ефективності педагогічної діяльності.

Дослідники вважають, що неможливо звести умови тільки до зовнішніх обставин, до сукупності об'єктів, які впливають на процес, тому що формування особистості являє собою єдність суб'єктивного й об'єктивного, внутрішнього й зовнішнього, сутності й явища (В. Беліков, В. Кондрух [2]).

Як зазначає А. Найн, педагогічні умови - це сукупність об'єктивних можливостей змісту, форм, методів, прийомів, засобів педагогічного управління та матеріально-просторового середовища, що забезпечують успішне вирішення поставлених і спроектованих завдань [14].

Сутність педагогічних умов полягає в синтезі об'єктивних можливостей змісту освіти, методів, організаційних форм і матеріальних можливостей, які сприяють розв'язанню поставлених педагогічних завдань [7, с. 193]. Педагогічні умови - це створені зусиллями колективу умови для покращення навчального процесу, це система органічно пов'язаних між собою психічних та практичних дій, спрямованих на розв'язання конкретних педагогічних завдань навчання, які $\epsilon$ обов'язковими для майбутніх фахівців [11, с. 40].

Як показує досвід, професійна підготовка майбутніх медичних працівників набуває більшої ефективності в межах педагогічно комфортного професійно орієнтованого освітнього середовища.

Професійно орієнтоване освітнє середовище визначають як сукупність умов, за допомогою яких створюється сприятливий клімат для актуалізації потенціалу всіх учасників освітнього процесу [12]; як педагогічну реальність зі спеціально організованими умовами для формування творчої індивідуальності студентів та їхньої самореалі- 
зації, в якій стосунки між учасниками освітнього процесу набувають характеру взаємного спілкування, співтворчості [10].

Проектування освітнього середовища у медичному ЗВО відкриває перспективи до нового типу взаємодії діяльності суб'єктів освітнього середовища закладу освіти. Різноманітність факторів, які потрібно враховувати у процесі створення проектної моделі, передбачає їх осмислення й зіставлення, на цій основі в ході проектування відбувається постійне «просторове» вирішення суперечностей і створюється цілісна модель середовища [28].

Як зазначає I. Габа [5], будь-яке проектування передбачає вирішення цілого ряду організаційних завдань, стратегії власне проектувальної діяльності, перебудови темпоральної структури діяльності людини (проектувальника) та її найближчого оточення. Етап обмірковування організаційно-діяльнісних аспектів вирішення проблеми в процесі проектування завжди пов'язаний з онтологічним (для чого потрібно вирішити дану проблему, в чому сенс діяльності по знаходженню цього рішення) і аксіологічним початком, цінностями суб' єкта проектування (яку особисто значущу цінність може мати ця діяльність і для подальшої життєтворчості проектанта, і для його особистісного саморозвитку) [там само].

Освітнє середовище має свою структуру, характеристики, особливості, безпосередньо та опосередковано впливає на становлення майбутнього фахівця, формування його професійної компетентності $[21$, c. 78$]$.

Розуміючи під освітнім середовищем ЗВО динамічну єдність суб'єктів освітнього процесу та системи їхньої взаємодії, І. Габа визначає специфіку організації освітнього середовища, яка полягає у його розвивальному потенціалі як сукупності різноманітних можливостей навчально-професійного розвитку особистості, завдяки яким актуалізуються іiї перцептивні та когнітивні процеси, ефективні види соціальної взаємодії, сприяючи практичному засвоєнню різноманітних соціальних та предметних технологій та забезпечуючи процес становлення суб'єктності студента і викладача [5]. Особливо значущим у цьому контексті $є$ передбачення та прогнозування наставниками-викладачами результатів діяльності майбутніх медичними сестер у межах професійно орієнтованого освітнього середовища. 
Структурними компонентами освітнього середовища є: суб’єктний (для розвитку пізнавальних процесів і навичок, засвоєння соціального досвіду необхідні наявність суб'єктів, які його мають і передають за допомогою взаємодії, певних засобів і технологій); соціальний (формування та розвиток професійних умінь, навичок, компетенцій на рівні репродукції, відтворення); продуктивно-діяльнісний (самостійний пошук, удосконалення відомих дій, операцій, створення умов); просторово-предметний (розвиток спілкування та дії - неможливі без досвіду комунікаційних процесів з іншими суб'єктами, опанування ефективними технологіями в певних умовах).

Формування якостей особистості здійснюється в культурному середовищі, яке має загальні та локальні цінності, традиції, ідеали, моделі поведінки, вимоги; «особистість виховує особистість». На думку Г. Полякової, в освітньому середовищі кожен його суб'єкт змінюється сам, змінює ситуацію навколо себе, наповнює освітнє середовище новими знаннями, досвідом, способами діяльності, формує нові потреби [21, с. 86].

Педагогічно комфортне середовище - це педагогічна реальність, що містить спеціально організовані умови для сприятливого проходження формування професійної індивідуальності студента, та можливості для їхньої самореалізації, при цьому стосунки між учасниками освітнього процесу набувають характеру взаємного спілкування, співтворчості [10].

Необхідними складниками педагогічно комфортного середовища $\epsilon$ доброзичлива атмосфера, ситуація успіху, імпровізація (як уміння сфокусувати сили душі й розуму, запаси пам'яті), що має стати пусковим механізмом у складному процесі активізації професійних можливостей майбутніх медичних сестер. У такому середовищі відбувається взаємодія студента 3 педагогом-наставником, створюється можливість формування індивідуалізованої освітньої траєкторії.

Створення в медичному ЗВО професійно орієнтованого освітнього середовища, адаптованого до потреб майбутньої фахової діяльності, сприяє:

- встановленню гуманістичних міжособистісних відносин як базової основи формування основ професіоналізму майбутніх медичних працівників;

- використанню індивідуальних, колективних навчально-практичних завдань, що стимулюють розвиток уміння працювати в команді; 
- поєднанню індивідуальної та колективної форм навчальної діяльності студентів-медиків;

- конструюванню професійно-медичних ситуацій, що стимулюють розвиток професійної свідомості й культури спілкування студентів як медичних працівників;

- розвитку самостійності майбутніх медичних працівників;

- набуттю ними досвіду майбутньої професійної діяльності, постійному саморозвитку спрямованому на використання на практиці набутих спеціальних знань і виконання фахових функцій;

- включенню студентів у «імпровізоване поле діяльності» 3 метою забезпечення адекватних дій, притаманних професії медичного працівника;

- залученню майбутніх медичних працівників до проектної діяльності, спрямованої на засвоєння програмового матеріалу та практичних навичок;

- посиленню професійної спрямованості навчання; забезпеченню взаємозв'язку медичного ЗВО з фаховим середовищем;

- пошуку нових технологій реалізації співпраці викладача зі студентами в навчальному процесі для спільного вирішення професійних завдань;

- розробці методичних основ рольової поведінки майбутніх медичних працівників;

- підвищенню конкурентоспроможності та мобільності випускників вищих медичних навчальних закладів.

Нами запропоновано тематичний план семінару «Професійно орі$є$ єнтоване освітнє середовище як умова формування професіоналізму медичних працівників», розрахований на 36 годин.

Тема 1. Зміст і сутність поняття «професіоналізм медичних працівників».

Тема 2. Професійно орієнтоване освітнє середовище - умова ефективності процесу формування професіоналізму медичних працівників.

Тема 3. Структура професійно орієнтованого освітнього середовища.

Тема 4. Умови створення професійно орієнтованого освітнього середовища в медичному ЗВО.

Тема 5. Педагогічна взаємодія викладачів і студентів в умовах професійно орієнтованого освітнього середовища закладу вищої медичної освіти. 
Тема 6. Імпровізація клінічних сценаріїв у контексті професійно орієнтованого освітнього середовища медичного ЗВО.

Тема 7. Інтерактивні методи начання майбутніх медичних працівників у межах професійно орієнтованого освітнього середовища медичного 3ВО.

Тема 12. Вплив освітнього середовища на формування професіоналізму майбутніх медичних працівників.

Після проведення семінару було організовано закрите «сліпе опитування», за результатами якого встановлено, що його робота на 97\% задовольнила пізнавально-методичні потреби учасників семінару - викладачів медичного університету, задіяних в педагогічному експерименті.

Наведемо кілька найтиповіших відгуків учасників семінару:

- Участь у методичному семінарі «Професійно орієнтоване освітнє середовище як умова формування основ професіоналізму майбутніх медичних працівників» збагатила знаннями щодо педагогічної взаємодії викладачів і студентів в умовах професійно орієнтованого освітнього середовища медичного коледжу, що осучаснює підхід до професійної підготовки майбутніх медичних сестер, забезпечує зв'язок навчання з практикою майбутньої професійної діяльності фахівців сестринської справи (Інна Едуардівна, викладач вищої кваліфікаційної категорії, педагогічний стаж - 19 років).

- Цікаво, науково-методично, доступно - так можна охарактеризувати проведений методичний семінар «Професійно орієнтоване освітнє середовище як умова формування основ професіоналізму майбутніх медичних працівників». Оволодіння запропонованими навчальними прийомами та формами роботи на заняттях з вивчення спеціальних дисциплін суттєво підвищить якість засвоєння студентами нових знань (Артур Олегович, кандидат медичних наук, доцент, педагогічний стаж - 16 років).

- Дякую за організацію семінару «Професійно орієнтоване освітнє середовище як умова формування основ професіоналізму майбутніх медичних працівників». Хоч і маю багатий власний педагогічний досвід, але заняття семінару виявилися надзвичайно важливим методичним і тееоретичним підгрунтям для практичної керівної, організаторської та навчальної діяльності в медичному коледжі (Олександр Іванович - кандидат медичних наук, доцент, педагогічний стаж - 37 років). 
- Проведення семінару на тему «Професійно орієнтоване освітнє середовище як умова формування основ професіоналізму майбутніх медичних працівників» особисто для мене було важливим моментом у професійній діяльності. Виявляється, основа основ - освітнє середовище, в якому відбувається фахова підготовка майбутніх медичних працівників. Необхідно всім колективом викладачів докласти максимум зусиль для створення такого професійно орієнтованого освітнього середовища (Анжела Сергіївна, кандидат медичних наук, педагогічний стаж - 15 років).

- Під впливом методичного семінару «Професійно орієнтоване освітнє середовище як умова формування основ професіоналізму майбутніх медичних працівників» я активізувала роботу з самоосвіти, намагаюся виконувати всі заходи щодо створення такого освітнього середовища в нашому коледжі (Світлана Петрівна, кандидат медичних наук, педагогічний стаж - 12 років).

Створення у медичному ЗВО професійно орієнтованого освітнього середовища, адаптованого до потреб майбутніх медичних працівників сприяє:

- включенню студентів в «імпровізоване поле діяльності» 3 метою забезпечення професійної атмосфери для розвитку практичних умінь та навичок, адже імпровізація - це вища художня невимушеність, у якій «рука ніби сама веде думку і створене фіксується підхоплюється і, оцінюється автором лише постфактум». Головним завданням імпровізації $\epsilon$ поставити студентів у творчу позицію, добиватися від них вражаючих творчих результатів, нешаблонності мислення і сприймання [23];

- включенню студентів у творчу проектну діяльність, спрямовану на засвоєння програмового матеріалу через створення та публічного захисту творчого проекту, адже цілеспрямоване включення до процесу проектування імпровізованих творчих завдань як основи творчого проекту стає вихідним механізмом для практики майбутньої професійної діяльності;

- рефлексивній самоорганізації творчої самостійності майбутніх лікарів, що передбачало розвиток інтелектуальної сфери студентів-медиків;

- розвитку самостійності майбутніх лікарів, набуттю ними досвіду майбутньої професійної діяльності, їхньому перманентному саморозвитку з проекцією на лікарську практику й виконання фахових функцій; 
- забезпеченню взаємозв'язку медичного вишу з фаховим лікарським середовищем, посилення професійної спрямованості навчання, адже щоб стати лікарем за посадою, відчути себе частиною процесу охорони здоров'я та усвідомлювати своє професійне призначення й себе у професії;

- пошук нових технологій реалізації співтворчості викладача і студента в навчальному процесі для спільного вирішення професійних і творчих завдань, розробка методичних основ рольової поведінки майбутніх лікарів як суб'єктів взаємодії в процесі активної участі в роботі університетської клініки;

- формуванню творчої індивідуальності майбутніх лікарів, саморозвитку й самовдосконаленню студентів-медиків;

- збагаченню досвіду творчого пошуку шляхів розв'язання проблеми і творчої самореалізації майбутніх лікарів.

Модернізація освітнього середовища відбувалася і шляхом його адаптації до сучасних вимог до фахової діяльності медичних працівників згідно зі світовими стандартами було спрямовано й навчальну та виробничу практику в медичному ЗВО.

Практика (від грец. practicos - діяльний, активний) - матеріальна, цілеспрямована діяльність людей; засвоєння і перетворення об'єктивної дійсності; основа розвитку людського суспільства та пізнання [20].

Згідно з Положенням про проведення практики студентів у вищих навчальних закладах України [19], практика студентів $є$ невід'ємною складовою процесу підготовки спеціалістів у вищих навчальних закладах.

Практика - це вид навчальних занять, в процесі яких студент самостійно виконує в умовах діючого виробництва реальні виробничі завдання, визначені навчальною програмою [18].

Виробнича практика в межах ЗДМУ відповідно до положення про організацію та проведення практики студентів передбачає нижчезазначені пункти.

1. Виробнича практика має на меті набуття студентами професійних навичок зі спеціальності, систематизацію, закріплення та розширення знань, отриманих під час вивчення циклу професійної і практичної підготовки, розвиток професійного мислення, прищеплених умінь організаторської діяльності в умовах лікувально-профілактичного закладу. 
2. Виробнича практика проводитися на базах лікувально-профілактичних, фармацевтичних та інших медичних закладів, які закріплені за вищим навчальним закладом наказом місцевих органів охорони здоров'я або мають з ним відповідні угоди.

3. Після проходження виробничої практики складається диференційований залік, який приймається методичним керівником від навчального закладу та безпосереднім і загальним керівником від лікувально-профілактичної установи. Оцінка 3 практики вноситься в залікову відомість за підписом членів комісії.

Отже, сучасна професійна підготовка майбутніх працівників неможлива без модернізації освітнього середовища, що є однією 3 основних умов їхньої ефективної підготовки й передбачає створення інноваційних систем професійного становлення з урахуванням передбачених змін і наслідків їхнього впливу на майбутню професійну діяльність у сфері охорони здоров’я.

\section{4. Педагогічна майстерність викладачів-клініцистів}

У зв'язку з загостренням актуальності проблеми охорони і зміцнення здоров'я людей постають нові вимоги до змісту та якості підготовки майбутніх лікарів 3 високим рівнем сформованості професійно значущих рис і творчого потенціалу, які здатні якісно й сумлінно виконувати свої професійні функції та соціальну роль. Актуалізується потреба в правильних акцентах у навчанні студентів медичних вищих навчальних закладів з метою формування фахової культури і професіоналізму, взаємопов'язаних суспільно цінних рис, більшість з яких формуються у процесі професійної підготовки.

Як зазначено в Законі України «Основи законодавства України про охорону здоров'я» [6], професійна підготовки майбутніх лікарів має бути орієнтована на формування не лише лікарської компетентності, а й готовності випускників медичних ЗВО до участі в забезпеченні гармонійного розвитку фізичних і духовних сил, високої працездатності й довголітнього активного життя громадян, усунення факторів, що шкідливо впливають на їхнє здоров'я.

Як учень починається 3 учителя, так і медичний працівник починається з викладача-наставника, особливо клінічних дисциплін. Від особистості педагога, його майстерності багато в чому залежить 
успіх продуктивної професійної діяльності майбутніх медичних працівників. Пошук шляхів удосконалення педагогічної майстерності викладачів медичних ЗВО наразі $є$ актуальною проблемою, оскільки педагог-новатор здатний забезпечити результативність й ефективність освітнього професійно орієнтованого процесу.

Зараз у світі професія медичного працівника, зокрема лікаря, набуває нових висот, нового розвитку.

Сьогодні, на жаль, доводиться констатувати, що багато викладачів закладів вищої медичної освіти орієнтовані, в основному на традиційний підхід, але ж сьогодні необхідний інше ставлення до освітнього процесу. Він являє собою органічне поєднання класичних та інноваційних методів, впровадження інноваційних форм і методів навчання, нових освітніх та інформаційних технологій для прищеплення у студентів самостійності, ініціативності, активності в навчанні. Перш, ніж розкрити, навчити і прищепити такі навички у студентів, необхідно розвинути їх у самих викладачів, зокрема тих, які працюють у медичних 3ВО.

На думку І. Зязюна, майстерність - багатоаспектне утворення, «це - особливий стан, який уможливлює рівень професійної свободи вчителя, педагога, вихователя, керівника навчального закладу, визначаючи межі можливого й внутрішньо дозволеного у педагогічній реальності». Вчений виходить 3 того, що педагогічна майстерність $\epsilon$ своєрідним підсумком професійного розвитку людини, виражаючи досягнення чи повноту професійної якості [8].

Педагогічна майстерність, за словами А. Маркової, - це гарне володіння основами професії, успішне застосування відомих у науці й практиці прийомів. Майстерність означає добрі знання педагогом свого навчального предмета, досягнення стабільних високих результатів у навченості, переважно у знаннях учнів. Кожен педагог при бажанні й наполегливості може стати майстром своєї справи [13].

Оскільки освітній процес - явище двостороннє, то тісна співпраця, доброзичливі взаємини між студентством та викладацьким складом одне 3 доданків успіху та якості навчального процесу. Дуже доречною в цьому контексті є думка О. Булатової [3] про те, що суб'єкт-суб'єктні взаємини між викладачем та учнем передбачають необхідність особливої «технології дотику» до особистості того, хто навчається, й надають педагогічному процесу рис, що поєднують педагогіку й мистецтво. 
Кодекс професійної етики педагога відображає етичні стандарти й моральні цінності, забезпечує стабільність і якість навчального процесу. Етичні норми в системі освіти неможливі без верховенства закону, демократичних процедур і стандартів, які, безсумнівно, повинні бути дотримані та відображені в Кодексі. Кодекс професійної етики головним метою ставити пропаганду і підтримання високих етичних норм професійної діяльності, поведінки, взаємин у академічній спільноті. Він визначає принципи діяльності, стандарти професійної поведінки та ділової етики викладача у взаєминах з колегами, зі студентами та органами управління навчального закладу.

Педагогічна майстерність викладача повинна проявлятися постійно: під час навчальних занять (як лекційних, так і практичних, семінарських, лабораторних) і в процесі позааудиторної роботи. Викладач власним прикладом має показувати взірець дотримання етичного Кодексу.

Проте слід зауважити, що впродовж останніх років у суспільстві відбувається зміна уявлень про моральність, втрати здатності до емоційної співчутливості, «механістичне» ставлення до пацієнтів. Щоб у цьому переконатися, потрібно відвідати будь-яку державну поліклініку або лікарню, принаймні в більшості з них можна спостерігати явища низької емоційної співчутливості та інші негативні явища. Якщо у медичних працівників зі значним стажем роботи це можна пояснити синдром «вигорання» або розчаруванням у соціальних гарантіях держави, то для молодих спеціалістів, які тільки-но приступають до своїх обов'язків, корені подібної поведінки потрібно шукати в системі фахової медичної освіти.

Таким чином, наразі необхідно створити методичне забезпечення обміну передовим педагогічним досвідом викладачів медичних 3ВО; проводити тематичні педагогічні ради з питань розвитку та збагачення майстерності педагогів, в тому числі - клініцистів; здійснювати політику по розширенню прав і повноважень; розвивати міжнародне співробітництво у сфері впровадження інноваційних технологій з підвищення педагогічної майстерності викладачів-клініцистів; створювати інтерактивні мережі, забезпечувати академічну мобільність студентів і викладачів та, звичайно, лікарів-практиків.

Оновлення системи науково-методичної роботи нерозривно пов'язане 3 розвитком нового педагогічного мислення, вивченням інно- 
ваційних технологій навчання, що базуються на комп’ютерній підтримці навчальної діяльності та інтенсифікації навчального процесу, підвищує ефективність навчально-виховного процесу та професійний рівень педагогів [17].

Доводиться констатувати, що сучасний стан професійної підготовки майбутніх медичних працівників в Україні засвідчує той факт, що більшість представників викладацького складу медичних $3 \mathrm{BO}$ - це, насамперед, колишні випускники медичних університетів або лікарі, які поєднують викладацьку діяльність з професією лікаря. Налічується невелика кількість викладачів-лікарів, які пройшли спеціальну педагогічну підготовку в магістратурі за спеціальністю «Педагогіка вищої школи» (так, наприклад, у Медичному коледжі Запорізького державного медичного університету лише 13\% відсотків викладачів мають педагогічну освіту, решта представників викладацького складу - лікарі-клініцисти).

Вважаємо, що лише за умови психолого-педагогічної підготовки викладачів медичних коледжів до виконання завдань професійної освіти можливо підвищити ефективність процесу формування професіоналізму майбутніх медичних сестер під час фахової підготовки.

3 метою вдосконалення педагогічної майстерності викладачів-клініцистів медичного ЗВО засобами науково-методичної роботи нами розроблено низку занять науково-методичного семінару «Педагогічні технології формування основ професіоналізму майбутніх медичних працівників» (зокрема, «Особливості впровадження у навчальний процес медичного ЗВО нових педагогічних технологій, активних форм і методів навчання», «Попереднє проектування навчально-виховного процесу за допомогою педагогічної технології» тощо); щомісячні майстер-класи, методичні наради; відкриті лекційні, семінарські та практичні заняття; розроблено методичні рекомендації щодо впровадження в освітній процес медичного ЗВО інтерактивних форм і засобів формування у майбутніх лікарів клінічного мислення та культури професійного спілкування, що суттєво вплинуло на підвищення якості й ефективності їхньої фахової підготовки.

Теми семінару «Педагогічні технології формування основ професіоналізму майбутніх медичних працівників: «Педагогічна технологія як змістовна техніка реалізації сучасного освітнього процесу»; «Тех- 
нологічний підхід до формування професіоналізму майбутніх медичних працівників: теорія та практика»; «Особливості впровадження в освітній процес медичного ЗВО нових педагогічних технологій, активних форм і методів навчання»; «Попереднє проектування освітнього процесу за допомогою педагогічної технології»; «Педагогічна технологія як системна сукупність і порядок функціонування особистісних, інструментальних і методологічних засобів, що використовуються для досягнення педагогічної мети»; «Педагогічна технологія як система методів професійної підготовки майбутніх лікарів»; «Педагогічна технологія як показник системи дій викладача і студентів у контексті фахової підготовки майбутніх медичних працівників».

Після проведення науково-методичного семінару для викладачів медичного університету було проведено анкетування, що засвідчило позитивні відгуки педагогів-наставників, які висловили свою думку щодо ефективності впровадження в практику професійної підготовки медиків інноваційних педагогічних технологій.

\section{5. Висновки}

Отже, ефективними й дієвими, виявилися такі форми роботи щодо вдосконалення педагогічної майстерності викладачів-клініцистів медичного 3ВО: науково-методичний семінар «Педагогічні технології формування основ професіоналізму майбутніх лікарів»; щомісячні майстер-класи, методичні наради; відкриті лекційні, семінарські та практичні заняття; авторські методичні рекомендації та розробки щодо впровадження в освітній процес медичного коледжу інтерактивних форм і засобів формування у майбутніх лікарів клінічного мислення та культури професійного спілкування, що суттєво вплинуло на підвищення ефективності їхньої фахової підготовки.

\section{Список літератури:}

1. Атаманчук П.С. Управління процесом навально-пізнавальної діяльності. Київ : ПДПІ, 1997. 136 с.

2. Беликов В.А. Педагогические условия как цель педагогических исследований. Проблемы образования и развития личности учащихся. Магнитогорск : МаГУ, 2001. С. 69-73.

3. Булатова О.С. Педагогический артистизм. Москва : Академия, 2001. 240 с.

4. Бусел В.Т. Великий тлумачний словник сучасної української мови. Київ : ВТФ «Перун», 2002. 1440 с. 
5. Габа I. Соціально-психологічні особливості проектування освітнього середовища ВНЗ у контексті розвивального потенціалу. URL: https://docviewer.yandex.ua/?url=http\%3A\%2F\%2Fvisnyk.chnpu.edu.ua.

6. Закон України «Основи законодавства України про охорону здоров'я». URL: http://bs-staff.com.ua/pb_ot/1085_165_37.html

7. Занаюк С.С. Психология мотивации. Киев : Эльга-Н; Ника-Центр, 2002. $352 \mathrm{c}$.

8. Зязюн І.А. Педагогічна майстерність: проблеми, пошуки, перспективи : монографія. Київ, Глухів : РВВ ГАПУ, 2005. С. 10-18.

9. Карамушка Л.М. Психологія освітнього менеджменту : навч. посібник. Київ : Либідь, 2004. 424 с.

10. Качалов А.В. Педагогические условия формирования творческой самостоятельности студентов педвуза. Известия Уральского государственного университета. 2009. № 1/2(62). С. 212-217.

11. Левченко T.I. Розвиток освіти та особистості. Вінниця : Нова Книга, $2002.510 \mathrm{c}$.

12. Лошакова Т.Ф. Педагогическое управление процессом создания комфортной среды в образовательном учреждении : монография. Екатеринбург, $2001.416 \mathrm{c}$.

13. Маркова А.К. Психология профессионализма. Москва:Международный гуманитарный фонд «Знание», 1996. 312 с.

14. Найн А.Я. О методологическом аппарате диссертационных исследований. Педагогика. 1995. № 5. С. 44-49.

15. Національна доктрина розвитку освіти України у XXI столітті. Ocвima. 2002. № 26. C. 2-4.

16. Нісімчук А.С. Педагогіка : підручник. Київ : Атака, 2007. 344 с.

17. Павленко Л.А. Впровадження інноваційних освітніх технологій як основа оновлення системи науково-методичної роботи закладу освіти. URL: http://virtkafedra.ucoz.ua/el_gurnal/pages/vyp7/konf2/Pavlenko_LA.pdf

18. Педагогічний словник / за ред. Ярмаченка М.Д. Київ : Педагогічна думка, 2001.514 с.

19. Положення про проведення практики студентів вищих навчальних закладів України : Наказ № 93 Міністерства освіти і науки України від 08.04.1993 p. URL: http://zakon4.rada.gov.ua/laws/show/z0035-93

20. Полонский В.М. Словарь по образованию и педагогике. Москва : Высшая школа, 2004. 512 с.

21. Полякова Г. Вплив освітнього середовища ВНЗ на формування професійної компетентності фахівців. Вищза школа. 2010. № 10. С. 78-87.

22. Професійна освіта : словник. Київ, 2000. 380 с.

23. Рунин Б.М. Психология импровизации. URL: http://www.aquarun.ru/ $\mathrm{psih} / \mathrm{tvor} / \mathrm{tvor} 31 . \mathrm{html}$

24. Симонов В.П. Педагогический менеджмент : учебное пособие. Москва, 1997. $216 \mathrm{c}$.

25. Словник-довідник з професійної педагогіки. Одеса : Пальміра, 2006. $362 \mathrm{c}$. 
26. Словник іншомовних слів: 23000 слів та термінологічних словосполучень. Київ : Довіра, 2000. 1018 с.

27. Титаренко Т.М. Сучасна психологія особистості. Київ : Марич, 2009. $232 \mathrm{c}$.

28. Ткач Т.В. Освітній простір особистості: психологічний аспект : монографія. Київ, 2008. 272 с.

29. Філософський словник соціальних термінів. 3-тє вид., доповн. Київ, $2005.670 \mathrm{c}$.

30. Фролов Ю.В., Махотин Д.А. Компетентностная модель как основа оценки качества подготовки специалистов. Высшее образование сегодня. 2004. № 8. C. 34-41.

31. Харламов И.Ф. Педагогика. Курс лекций. Москва, 1999. 520 с.

32. Хміль Ф.І. Основи менеджменту. Київ : Академвидав, 2007. 576 с.

33. Шамова Т.И. Управление образовательными системами : учебное пособие. Москва, 2002. 354 с.

34. Яковлева Н.М. Подготовка студентов к творческой воспитательной деятельности. Челябинск : ЧГПИ, 1991. 82 с.

\section{References:}

1. Atamanchuk P.S. Upravlinnja procesom navaljno-piznavaljnoji dijaljnosti. Kyiv: PDPI, 1997. $136 \mathrm{~s}$.

2. Belikov V.A. Pedagogicheskie uslovija kak cel' pedagogicheskih issledovanij. Problemy obrazovanija i razvitija lichnosti uchashhihsja. Magnitogorsk: MaGU, 2001. S. 69-73.

3. Bulatova O.S. Pedagogicheskij artistizm. Moskva: Akademija, 2001. 240 s.

4. Busel V.T. Velykyj tlumachnyj slovnyk suchasnoji ukrajinsjkoji movy. Kyjiv: VTF «Perun», 2002. $1440 \mathrm{~s}$.

5. Ghaba I. Socialjno-psykhologhichni osoblyvosti proektuvannja osvitnjogho seredovyshha VNZ u konteksti rozvyvaljnogho potencialu. URL: https://docviewer.yandex.ua/?url=http\%3A\%2F\%2Fvisnyk.chnpu.edu.ua

6. Zakon Ukrajiny «Osnovy zakonodavstva Ukrajiny pro okhoronu zdorov'ja». URL: http://bs-staff.com.ua/pb_ot/1085_165_37.html

7. Zanajuk S.S. Psihologija motivacii. Kiev: Jel'ga-N; Nika-Centr, 2002. $352 \mathrm{~s}$.

8. Zjazjun I.A. Pedaghoghichna majsternistj: problemy, poshuky, perspektyvy: monoghrafija. Kyjiv, Ghlukhiv: RVV GhAPU, 2005. S. 10-18.

9. Karamushka L.M. Psykhologhija osvitnjogho menedzhmentu: navch. posibnyk. Kyiv: Lybidj, 2004. $424 \mathrm{~s}$.

10. Kachalov A.V. Pedagogicheskie uslovija formirovanija tvorcheskoj samostojatel'nosti studentov pedvuza. Izvestija Ural'skogo gosudarstvennogo universiteta. 2009. № 1/2(62). S. 212-217.

11. Levchenko T.I. Rozvytok osvity ta osobystosti. Vinnycja: Nova Knygha, 2002. $510 \mathrm{~s}$.

12. Loshakova T.F. Pedagogicheskoe upravlenie processom sozdanija komfortnoj sredy v obrazovatel'nom uchrezhdenii: monografija. Ekaterinburg, 2001. $416 \mathrm{~s}$. 
13. Markova A.K. Psihologija professionalizma. Moskva: Mezhdunarodnyj gumanitarnyj fond «Znanie», 1996.312 s.

14. Najn A.Ja. O metodologicheskom apparate dissertacionnyh issledovanij. Pedagogika. 1995. № 5. S. 44-49.

15. Nacionaljna doktryna rozvytku osvity Ukrajiny u KhKhI stolitti. Osvita. 2002. № 26. S. 2-4.

16. Nisimchuk A.S. Pedaghoghika: pidruchnyk. Kyiv: Ataka, 2007. 344 s.

17. Pavlenko L.A. Vprovadzhennja innovacijnykh osvitnikh tekhnologhij jak osnova onovlennja systemy naukovo-metodychnoji roboty zakladu osvity. URL: http://virtkafedra.ucoz.ua/el_gurnal/pages/vyp7/konf2/Pavlenko_LA.pdf

18. Pedaghoghichnyj slovnyk/za red. Jarmachenka M.D. Kyiv: Pedaghoghichna dumka, 2001. $514 \mathrm{~s}$.

19. Polozhennja pro provedennja praktyky studentiv vyshhykh navchaljnykh zakladiv Ukrajiny: Nakaz №93 Ministerstva osvity i nauky Ukrajiny vid 08.04.1993 r. URL: http://zakon4.rada.gov.ua/laws/show/z0035-93

20. Polonskij V.M. Slovar' po obrazovaniju i pedagogike. Moskva: Vysshaja shkola, 2004. $512 \mathrm{~s}$.

21. Poljakova Gh. Vplyv osvitnjogho seredovyshha VNZ na formuvannja profesijnoji kompetentnosti fakhivciv. Vyshha shkola. 2010. № 10. S. 78-87.

22. Profesijna osvita: slovnyk. Kyiv, 2000. $380 \mathrm{~s}$.

23. Runin B.M. Psihologija improvizacii. URL: http://www.aquarun.ru/psih/ tvor/tvor31.html

24. Simonov V.P. Pedagogicheskij menedzhment: uebnoe posobie. Moskva, 1997. $216 \mathrm{~s}$.

25. Slovnyk-dovidnyk z profesijnoji pedaghoghiky. Odesa: Paljmira, 2006. $362 \mathrm{~s}$.

26. Slovnyk inshomovnykh sliv: 23000 sliv ta terminologhichnykh slovospoluchenj. Kyiv: Dovira, 2000. $1018 \mathrm{~s}$.

27. Tytarenko T.M. Suchasna psykhologhija osobystosti. Kyjiv: Marych, 2009. 232 s.

28. Tkach T.V. Osvitnij prostir osobystosti: psykhologhichnyj aspekt: monoghrafija. Kyiv, 2008. $272 \mathrm{~s}$.

29. Filosofsjkyj slovnyk socialjnykh terminiv. 3-tje vyd., dopovn. Kyiv, 2005. $670 \mathrm{~s}$.

30. Frolov Ju.V., Mahotin D.A. Kompetentnostnaja model' kak osnova ocenki kachestva podgotovki specialistov. Vysshee obrazovanie segodnja. 2004. № 8. S. $34-41$.

31. Harlamov I.F. Pedagogika. Kurs lekcij. Moskva, 1999. 520 s.

32. Khmilj F.I. Osnovy menedzhmentu. Kyiv: Akademvydav, 2007. 576 s.

33. Shamova T.I. Upravlenie obrazovatel'nymi sistemami: uchebnoe posobie. Moskva, 2002. $354 \mathrm{~s}$.

34. Jakovleva N.M. Podgotovka studentov $\mathrm{k}$ tvorcheskoj vospitatel'noj dejatel'nosti. Cheljabinsk: ChGPI, 1991. $82 \mathrm{s.}$ 